\title{
Bioactive Compounds, Antioxidant Capacity, and Fatty Acids in Different Parts of Four Unexplored Fruits
}

\author{
Adriela Albino Rydlewski, ${ }^{1}$ Damila Rodrigues de Morais, ${ }^{2}$ \\ Eliza Mariane Rotta, ${ }^{2}$ Thiago Claus, ${ }^{2}$ Julianna Matias Vagula, ${ }^{1}$ Michele Cristina da Silva, ${ }^{2}$ \\ Oscar Oliveira Santos Junior, ${ }^{2}$ and Jesuí Vergílio Visentainer ${ }^{1,2}$
}

${ }^{1}$ Food Science, Agricultural Science Center, State University of Maringá (UEM), 87020-900 Maringá, PR, Brazil

${ }^{2}$ Department of Chemistry, State University of Maringá (UEM), 87020-900 Maringá, PR, Brazil

Correspondence should be addressed to Adriela Albino Rydlewski; adrielaar@hotmail.com

Received 17 February 2017; Revised 20 March 2017; Accepted 6 April 2017; Published 24 April 2017

Academic Editor: Ángel A. Carbonell-Barrachina

Copyright (C) 2017 Adriela Albino Rydlewski et al. This is an open access article distributed under the Creative Commons Attribution License, which permits unrestricted use, distribution, and reproduction in any medium, provided the original work is properly cited.

\begin{abstract}
Total phenolic content (TPC), total flavonoids (TF), total anthocyanins (TA), and antioxidant capacity of different parts of four unexplored fruits from Brazil (Syzygium cumini Lam, Solanum nigrum Linn, Inga edulis Mart, and Hovenia dulcis Thunb) were determined; the bioactive compounds and fatty acids were quantified and identified by high-performance liquid chromatography and gas chromatography, respectively. S. cumini peels contained the most TA (63.31 mg/100 g), whilst $H$. dulcis pulp and peels had the highest TPC (518.18 mg GAE/100 g) and TF (76.54 mg EQ/g). Phenolic compounds responsible for antioxidant capacity of fruits were gallic acid, ellagic acid, kaempferol, and epicatechin. H. dulcis seed showed the highest level of the essential fatty acid omega-3 $(3985.95 \mathrm{mg} / 100 \mathrm{~g})$. PCA showed that PC1 and PC2 explained $90.43 \%$ of the total variability of the antioxidant data. Most of the seeds showed omega-3, omega-6, and omega-9 fatty acids at significant concentrations, with two PCs explaining $93.80 \%$ of the total variance of the fatty acid contents.
\end{abstract}

\section{Introduction}

Oxidative stress is caused by reactive oxygen species (ROS), which include free radicals (oxygen and nitrogen species), and this condition occurs when there is an overproduction of ROS and/or insufficient antioxidant mechanisms [1]. Among the main consequences of oxidative stress is damage to the biomolecules, particularly DNA, lipids, and proteins, which can severely compromise cell function and activate a cascade of free radical reactions. Oxidative stress may occur as a result of degenerative diseases or may also be a causative factor in the development of diseases. Arthritis, atherosclerosis, cancer, diabetes, and Parkinson's, for example, involve ROS [2].

The interest in studying unexplored species of fruits and their parts, such as peels and seeds, has increased in recent years because they are rich in phenolic compounds, flavonoids, anthocyanins, vitamins, minerals, and other bioactive compounds that are capable of neutralizing free radicals [3-5].
Moreover, fruits have essential polyunsaturated fatty acids (PUFAs), such as linoleic acid (LA, 18:2n-6) and alphalinolenic acid (LNA, 18:3n-3) that are considered essential because they cannot be synthesized by the human body and must be supplied through the diet [6]. These fatty acids (FAs) are able to protect against oxidative stress by exerting an antioxidant role [7]. Fruits also contain oleic acid (OA, 18:1n-9), which is widely recognized for its action in lowering the risk of ROS-induced diseases and enhancing the immune system [8]. Therefore, increased fruit consumption is associated not only with personal preference but also with the maintenance of health, through the consumption of foods rich in vital micronutrients $[7,9]$.

Several methods have been developed to measure the antioxidant capacity of fruits. In particular, the ferric reducing antioxidant power (FRAP) and 1,1-diphenyl-2-picrylhydrazyl $\left(\mathrm{DPPH}^{\circ}\right)$ assays have been widely adopted [7]. Association studies between fruit and vegetable consumption and 
TABLE 1: List of the four fruits included in this study.

\begin{tabular}{lccc}
\hline Common name & Scientific name & Family & Origin \\
\hline Jambolan & Syzygium cumini Lam & Myrtaceae & India \\
Black nightshade & Solanum nigrum Linn & Solanaceae & South Africa \\
Inga edulis & Inga edulis Mart & Leguminosae & Brazil, South and Central America \\
Japanese grape & Hovenia dulcis Thunb & Rhamnaceae & Japan, China, and Korea \\
\hline
\end{tabular}

indicators of oxidative stress using antioxidant assays have received the attention of researchers [10]. It is recommended that at least two methods with different mechanisms are combined to provide a reliable picture of the total antioxidant capacity of a food because the results can be affected using a single assay to evaluate the entire sample [11, 12].

Jambolan (Syzygium cumini Lam), black nightshade (Solanum nigrum Linn), inga edulis (Inga edulis Mart), and Japanese grape (Hovenia dulcis Thunb) are unexplored fruits and few studies have been published on characterizing the bioactive compounds and antioxidant capacity of the pulps, peels, and seeds of these fruits. Therefore, this study aimed to evaluate the $\mathrm{DPPH}^{\circ}$ and FRAP antioxidant capacities, the total phenolic content (TPC), total flavonoids (TF), and total anthocyanins (TA) and to identify and quantify the phenolic compounds and FAs by high-performance liquid chromatography (HPLC) and gas chromatography (GC), respectively.

\section{Materials and Methods}

2.1. Plant Material. The botanical identification and geographical origin of the four fruits are provided in Table 1. Fresh fruits (ca. $2 \mathrm{~kg}$ each) were harvested at Monte Alegre, São Paulo, Brazil $\left(23^{\circ} 35^{\prime} 31^{\prime \prime} \mathrm{S}\right.$ and $\left.48^{\circ} 38^{\prime} 38^{\prime \prime} \mathrm{W}\right)$. The fruits were washed with tap water and the pulps, peels, and seeds were removed manually, chopped, and then homogenized in a multiprocessor to uniformity before analysis. $H$. dulcis pulp and peels were evaluated together because it was not possible to separate them. I. edulis peels were discarded.

2.2. Chemical and Standards. Fatty acid methyl esters (FAME) (standard mixture 189-19), methyl tricosanoate (23:0), FolinCiocalteu phenol reagent, gallic acid, kaempferol, ellagic acid, epicatechin, quercetin, $\mathrm{DPPH}^{\bullet}$, 6-hydroxy-2,5,7,8tetramethylchromane-2-carboxylic acid (Trolox), 2,4,6-tris (2-pyridyl)-s-triazine (TPTZ), and methanol and acetonitrile (HPLC grade) were purchased from Sigma Chemical Co. (St. Louis, USA). Ultrapure water (Milli-Q system, Millipore Corp, Bedford, MA) was also used. All solvents and chemicals were of analytical grade.

2.3. Extraction of Antioxidants. The extracts were prepared using $10 \mathrm{~g}$ (per part of the fruit) in $100 \mathrm{~mL}$ of methanol under magnetic stirring for $4 \mathrm{~h}$ according to the method developed by Santos et al. [13]. After filtration, the extracts were concentrated under reduced pressure at $40^{\circ} \mathrm{C}$. The absorbance values obtained were within the calibration range of the respective methods (Genesys 10-UV scanning, Thermo Scientific). The results were expressed as fresh weight (FW).
2.4. Analysis of $\mathrm{DPPH}^{\circ}$ Antioxidant Capacity (Free RadicalScavenging Activity). The $\mathrm{DPPH}^{\bullet}$ scavenging capacity was measured using the method described by Brand-Williams et al. [14]. Briefly, an aliquot of the methanolic fruit extract $(25 \mu \mathrm{L})$ was added to $2 \mathrm{~mL}$ of $6.25 \times 10^{-5} \mathrm{~mol} / \mathrm{L} \mathrm{DPPH}{ }^{*}$ methanolic solution. After gently mixing and then resting the reaction solutions at room temperature for $30 \mathrm{~min}$, the absorbance was measured at $517 \mathrm{~nm}$. Methanolic solutions of known Trolox concentrations between 0 and $2000 \mu \mathrm{mol} / \mathrm{L}$ were used for calibration. The results were expressed as $\mu \mathrm{mol}$ Trolox equivalents (TE)/g FW using the calibration curve $\left(y=0.686-2.90 \times 10^{-4} x, r^{2}=0.997\right)$.

2.5. FRAP Assay. The FRAP assay was determined as previously described by Benzie and Strain [15]. FRAP reagent was prepared by mixing acetate buffer $(0.3 \mathrm{~mol} / \mathrm{L}, \mathrm{pH} 3.6)$, TPTZ $(10 \mathrm{mmol} / \mathrm{L})$, and $\mathrm{FeCl}_{3}(20 \mathrm{mmol} / \mathrm{L})$ solutions at $10: 1: 1$, respectively. An aliquot of the methanolic fruit extract $(100 \mu \mathrm{L})$ and $300 \mu \mathrm{L}$ of distilled water were added to $3 \mathrm{~mL}$ of the FRAP reagent and then placed in the dark for $30 \mathrm{~min}$ at $37^{\circ} \mathrm{C}$. The absorbance was measured against a blank at $593 \mathrm{~nm}$. Aqueous solutions of known $\mathrm{Fe}^{2+}$ concentrations between 0 and $1500 \mu \mathrm{mol} / \mathrm{L}\left(\mathrm{FeSO}_{4} \cdot 7 \mathrm{H}_{2} \mathrm{O}\right)$ were used for the calibration curve $\left(y=0.006+6.55 .10^{-4} x, r^{2}=0.999\right)$ and the results were expressed as $\mu \mathrm{mol} \mathrm{Fe} e^{2+} / \mathrm{g}$ FW.

2.6. TPC. The TPC were determined according to the procedure described by Shahidi and Naczk [16]. An aliquot of the methanolic fruit extract $(250 \mu \mathrm{L})$ was mixed with $250 \mu \mathrm{L}$ of the Folin-Ciocalteu reagent (prediluted in distilled water at $1: 1 \mathrm{v} / \mathrm{v}), 500 \mu \mathrm{L}$ of a saturated sodium carbonate solution, and $4 \mathrm{~mL}$ of distilled water. The reaction mixture was left to rest for $25 \mathrm{~min}$ and then centrifuged at $3000 \mathrm{rpm}$ (1638 g) for $10 \mathrm{~min}$. Then, the absorbance was measured at $725 \mathrm{~nm}$. Methanolic solutions of known gallic acid concentrations between 0 and $250 \mathrm{mg} / \mathrm{L}$ were used for calibration. The results were expressed as mg gallic acid equivalents (GAE) 100/g FW using the calibration curve $\left(y=-0.0273+0.00517 x, r^{2}=\right.$ 0.999).

2.7. TF. TF were determined according to Woisky and Salatino [17]. An aliquot of the methanolic fruit extract $(500 \mu \mathrm{L}, 2.5 \mathrm{mg} / \mathrm{ml})$ was added to $250 \mu \mathrm{L}$ of $\mathrm{AlCl}_{3}(5 \mathrm{~g} / 100 \mathrm{~mL}$ methanol) and $4.25 \mathrm{~mL}$ of methanol. After $30 \mathrm{~min}$, the absorbance was measured at $425 \mathrm{~nm}$. The results were expressed as mg quercetin equivalents ( $\mathrm{mg} \mathrm{QE} / \mathrm{g} \mathrm{FW}$ ) using the calibration curve $\left(y=-0.0273+0.00517 x, r^{2}=0.999\right)$.

2.8. TA. TA were extracted according to Lees and Francis [18]. An aliquot $(50 \mathrm{~g})$ was then homogenized with $50 \mathrm{~mL}$ of 
solvent $(70 \%$ ethanol acidified to $\mathrm{pH} 2.0$ with $0.1 \% \mathrm{HCl})$ for $2 \mathrm{~min}$. The volume was adjusted to $200 \mathrm{~mL}$ in a volumetric flask using the solvent, covered with parafilm, and stored at $4^{\circ} \mathrm{C}$ for $12 \mathrm{~h}$. Then, the material was filtered using a Büchner funnel and $125 \mathrm{~mL}$ of the filtrate mixed with another $250 \mathrm{~mL}$ of the solvent. Triplicate aliquots $(2 \mathrm{~mL})$ were adjusted to a final volume of $100 \mathrm{~mL}$ in a volumetric flask using the solvent. The reaction mixture was placed in the dark for $2 \mathrm{~h}$. Then, the absorbance was measured at $535 \mathrm{~mm}$. The results were expressed as mg 100/g FW.

2.9. Chromatographic Analysis. Total lipids (TL) were extracted by Bligh and Dyer [19] method. FAME were prepared by methylation of the TL as described by Hartman and Lago [20] and the methyl esters separated by GC in a Trace Ultra model 3300 (Thermo Scientific) equipped with a flame ionization detector (FID) and a cyanopropyl capillary column $(100 \mathrm{~m} \times 0.25$ i.d., $0.25 \mu \mathrm{m}$ film thickness, $\mathrm{CP7420})$. The gas flow rates were $1.2 \mathrm{Ml} / \mathrm{min}$ carrier gas $\left(\mathrm{H}_{2}\right)$, $30 \mathrm{~mL} / \mathrm{min}$ make-up gas $\left(\mathrm{N}_{2}\right)$, and 35 and $300 \mathrm{~mL} / \mathrm{min}$ flame gasses $\left(\mathrm{H}_{2}\right.$ and synthetic air, respectively). The split ratio was 1:80 and $2 \mu \mathrm{L}$ of the samples was injected in triplicate. The detector and injection port were set at $240^{\circ} \mathrm{C}$ and the column was set at $185^{\circ} \mathrm{C}$ for $7.5 \mathrm{~min}$. The peak areas were determined by ChromQuest 5.0 software. The FAs were identified by comparing their retention times with those of standard methyl esters.

Quantification (as mg FA/g of TL) was determined against tricosanoic acid methyl ester (23:0) as an internal standard (IS), as described by Joseph and Ackman [21]. Theoretical FID correction factor [22] values were used to obtain the concentrations. The FA contents were calculated as $\mathrm{mg} / \mathrm{g}$ TL using

$$
\mathrm{FA}(\mathrm{mg} / \mathrm{g} \mathrm{TL})=\frac{A_{X} \cdot W_{\mathrm{IS}} \cdot \mathrm{CF}_{X}}{A_{\mathrm{IS}} \cdot W_{X} \cdot \mathrm{CF}_{\mathrm{AE}}} \times 100,
$$

where FA is expressed as $\mathrm{mg} / \mathrm{g}$ of TL, $A_{X}$ is the peak area (FA), $A_{\text {IS }}$ is the peak area of the IS (the methyl ester of tricosanoic acid, 23:0), $W_{\text {IS }}$ is the IS mass (mg) of IS added to the sample (mg), $W_{X}$ is the sample mass (mg), $\mathrm{CF}_{X}$ is the theoretical correction factor, and $\mathrm{CF}_{\mathrm{AE}}$ is the conversion factor necessary to express results as mg of FA rather than as methyl esters.

2.10. Quantification of Phenolic Compounds by HPLC. The phenolic compounds were quantified according to Fratianni et al. [23] using a Thermo Scientific chromatograph, model Finnigan Surveyor PDA, with a manual injection valve, a photodiode array detection (DAD), connected to CromQuest 5.0 software and equipped with a EC 250/4.6 Nucleodur 100-5 C18ec column (Macherey-Nagel) $(250 \mathrm{~mm} \times$ $4.6 \mathrm{~mm}$ ). The mobile phases consisted of Milli-Q water (containing $1 \%$ acetic acid, phase $\mathrm{A}$ ) and acetonitrile (containing $1 \%$ acetic acid, phase B). The gradient started at $90 \% \mathrm{~A}$ and decreased to $60 \% \mathrm{~A}$ in $25 \mathrm{~min}$. After $26 \mathrm{~min}$, phase A returned to $90 \%$, where it remained until $35 \mathrm{~min}$ (total run time). The flow rate was $0.7 \mathrm{ml} / \mathrm{min}$, the injection volume was $50 \mu \mathrm{l}$, and the detection wavelengths were set at 250 and $270 \mathrm{~nm}$. The phenolic compounds of the methanolic fruit extracts were identified by comparison of their retention times with standards (Sigma) and UV-visible light spectra. The bioactive compounds were quantified by comparing the sample with the standard calibration curves.

2.11. Statistical Analysis. The data were analyzed using analysis of variance (ANOVA) and the means were compared by Tukey's test. The results were analyzed by principal component analysis (PCA) using Statistica 7.0 software. Data before treatment was not necessary.

\section{Results and Discussion}

3.1. TPC, TF, TA, and Antioxidant Capacity. The TPC, TF, and TA amounts and the antioxidant capacity ( $\mathrm{DPPH}^{\circ}$ and FRAP) of the different parts of the fruits are shown in Table 2. The TPC ranged from $19.27 \mathrm{mg}$ GAE/100 $\mathrm{g}$ in S. nigrum seeds to $518.18 \mathrm{mg} \mathrm{GAE} / 100 \mathrm{~g}$ in H. dulcis pulp and peels. The TPC in H. dulcis seed ( $85.56 \mathrm{mg} \mathrm{GAE} / 100 \mathrm{~g}$ ) was similar to that found by Santos et al. [13] in Benitaka and Brazil grape seed varieties (89.83 and $91.53 \mathrm{mg} \mathrm{GAE} / 100 \mathrm{~g}$, respectively). The TPC of $S$. nigrum pulps was $412.71 \mathrm{mg}$ GAE/100 g. This value can be compared to those of jaboticaba (440 mg GAE/100 g), açaí (454 mg GAE/100 g), and gurguri (549 mg GAE/100 g), in the study by Rufino et al. [9] because of the scarcity of studies on this particular fruit.

TF among the parts of the fruits varied from $2.59 \mathrm{mg}$ $\mathrm{EQ} / \mathrm{g}$ in I. edulis seeds to $76.54 \mathrm{mg} \mathrm{EQ} / \mathrm{g}$ in H. dulcis pulps and peels. According to Volp et al. [24], flavonoids are polyphenolic structures found naturally in plants and many of these flavonoids are responsible for the color of fruits. In the current study, $H$. dulcis pulp and peels revealed a higher TF value compared to the other pulps evaluated, which could be associated with the heavy pigmentation of these fruits.

Faria et al. [25] detected $91.2 \mathrm{mg} \mathrm{EQ/g} \mathrm{TF} \mathrm{in} \mathrm{S.} \mathrm{cumini.}$ These values were higher than those found in this study (59 $\mathrm{mg}$ and $65.51 \mathrm{mg} \mathrm{EQ} / \mathrm{g}$ in pulps and peels, respectively). In contrast, Benherlal and Arumughan [26] studied the same fruit and only found $7 \mathrm{mg} \mathrm{EQ} / \mathrm{g}$. These variations may occur due to the influence of various factors, such as climate conditions, geographic location, fruit maturation stage, and method used [25, 27].

The highest TA concentration was in S. cumini peels $(63.31 \mathrm{mg} / 100 \mathrm{~g})$. This value was lower than that found by Rufino et al. [9], when evaluating the combined peel and pulp of the fruit $(93.3 \mathrm{mg} / 100 \mathrm{~g})$ but higher when compared with jaboticaba $(58.1 \mathrm{mg} / 100 \mathrm{~g})$ and camu-camu $(42.2 \mathrm{mg} / 100 \mathrm{~g})$, in the same study. Relatively low TA concentrations were found in I. edulis pulps $(0.06 \mathrm{mg} / 100 \mathrm{~g})$ and none were found in the seeds of this fruit. The DPPH${ }^{\circ}$ antioxidant capacity was lower in the pulp of this fruit, compared to the other pulps evaluated in this study, in agreement with its lower content of bioactive compounds.

The $\mathrm{DPPH}^{\circ}$ antioxidant capacity of the fruit extracts varied from $68.66 \mu \mathrm{mol} \mathrm{TE} / \mathrm{g}$ in S. nigrum peels to $13240.60 \mu \mathrm{mol}$ $\mathrm{TE} / \mathrm{g}$ in $H$. dulcis peel and pulp. The FRAP antioxidant activity varied from $22.93 \mu \mathrm{mol} \mathrm{Fe} \mathrm{Fe}^{2+} / \mathrm{g}$ in $S$. nigrum seed to $690.68 \mu \mathrm{mol} \mathrm{Fe} \mathrm{Fe}^{2+} / \mathrm{g}$ in $H$. dulcis pulp and peel. Both methods indicated that $H$. dulcis pulp and peel had the 
TABLE 2: Total phenolic content (TPC, mg GAE/100 g), total flavonoids (TF, mg/EQ g), total anthocyanins (TA, mg/100 g), and antioxidant capacity by DPPH${ }^{*}(\mu \mathrm{mol} / \mathrm{TE} \mathrm{g})$ and FRAP $\left(\mu \mathrm{mol} / \mathrm{Fe}^{2+} \mathrm{g}\right)$ in different parts of fruits based on fresh weight $(\mathrm{FW})$.

\begin{tabular}{|c|c|c|c|c|c|}
\hline \multirow{2}{*}{ Parts of fruits } & \multicolumn{5}{|c|}{ Analysis } \\
\hline & TPC & $\mathrm{TF}$ & TA & $\mathrm{DPPH}^{\bullet}$ & FRAP \\
\hline \multicolumn{6}{|l|}{ Pulp } \\
\hline Syzygium cumini Lam & $313.66^{\mathrm{b}} \pm 8.93$ & $59.00^{\mathrm{b}} \pm 2.36$ & $9.26^{\mathrm{a}} \pm 0.41$ & $2810.90^{\mathrm{b}} \pm 114.56$ & $323.50^{\mathrm{b}} \pm 10.30$ \\
\hline Solanum nigrum Linn & $411.01^{\mathrm{a}} \pm 9.46$ & $55.42^{\mathrm{b}} \pm 5.95$ & $5.41^{\mathrm{b}} \pm 1.09$ & $1726.60^{\mathrm{bc}} \pm 105.83$ & $300.32^{\mathrm{b}} \pm 12.54$ \\
\hline Inga edulis Mart & $72.06^{c} \pm 7.36$ & $5.88^{\mathrm{c}} \pm 1.01$ & $0.06^{\mathrm{C}} \pm 0.05$ & $447.08^{\mathrm{c}} \pm 9.54$ & $41.27^{\mathrm{c}} \pm 3.61$ \\
\hline Hovenia dulcis Thunb & $518.18^{\mathrm{a}} \pm 30.89$ & $76.54^{\mathrm{a}} \pm 5.47$ & $10.76^{\mathrm{a}} \pm 1.14$ & $13240.60^{\mathrm{a}} \pm 309.61$ & $690.68^{\mathrm{a}} \pm 9.43$ \\
\hline \multicolumn{6}{|l|}{ Peel } \\
\hline Syzygium cumini Lam & $331.83^{\mathrm{a}} \pm 7.84$ & $65.51^{\mathrm{a}} \pm 7.34$ & $63.31^{\mathrm{a}} \pm 1.64$ & $2010.90^{b} \pm 32.49$ & $341.95^{\mathrm{b}} \pm 6.08$ \\
\hline Solanum nigrum Linn & $21.89^{\mathrm{b}} \pm 1.38$ & $43.39^{\mathrm{b}} \pm 5.44$ & $4.63^{c} \pm 0.12$ & $68.66^{c} \pm 1.27$ & $48.36^{\mathrm{c}} \pm 3.38$ \\
\hline Inga edulis Mart & NE & $\mathrm{NE}$ & NE & $\mathrm{NE}$ & $\mathrm{NE}$ \\
\hline Hovenia dulcis Thunb & $518.18^{\mathrm{a}} \pm 30.89$ & $76.54^{\mathrm{a}} \pm 5.47$ & $10.76^{\mathrm{b}} \pm 1.14$ & $13240.60^{\mathrm{a}} \pm 309.61$ & $690.68^{a} \pm 9.43$ \\
\hline \multicolumn{6}{|l|}{ Seed } \\
\hline Syzygium cumini Lam & $411.01^{\mathrm{a}} \pm 9.46$ & $38.97^{\mathrm{a}} \pm 3.37$ & $0.70^{\mathrm{b}} \pm 0.18$ & $10396.40^{\mathrm{a}} \pm 639.45$ & $209.30^{\mathrm{a}} \pm 3.77$ \\
\hline Solanum nigrum Linn & $19.27^{c} \pm 1.06$ & $10.24^{\mathrm{c}} \pm 1.42$ & $1.40^{\mathrm{a}} \pm 0.28$ & $95.12^{c} \pm 1.15$ & $22.93^{\mathrm{c}} \pm 1.11$ \\
\hline Inga edulis Mart & $66.32^{\mathrm{b}} \pm 8.68$ & $2.59^{\mathrm{d}} \pm 0.69$ & $\mathrm{ND}$ & $173.20^{c} \pm 12.43$ & $30.13^{c} \pm 3.46$ \\
\hline Hovenia dulcis Thunb & $85.56^{\mathrm{b}} \pm 7.28$ & $18.60^{\mathrm{b}} \pm 4.36$ & $1.51^{\mathrm{a}} \pm 0.25$ & $4877.50^{\mathrm{b}} \pm 195.27$ & $75.22^{\mathrm{b}} \pm 1.22$ \\
\hline
\end{tabular}

Results expressed as mean \pm standard deviation of three replicates. Equivalent parts of the different fruits were compared. Means followed by different letters in the same column are significantly different by Tukey's test $(p<0.05)$. H. dulcis pulp and peel were evaluated together. ND $=$ not detected. NE $=$ not evaluated.

TABLE 3: Quantification of phenolic compounds in different parts of fruits (mg/100 g FW).

\begin{tabular}{|c|c|c|c|c|}
\hline \multirow{2}{*}{ Parts of fruits } & \multicolumn{4}{|c|}{ Phenolic compounds } \\
\hline & Gallic acid & Kaempferol & Epicatechin & Ellagic acid \\
\hline \multicolumn{5}{|l|}{ Pulp } \\
\hline Syzygium cumini Lam & $5.59^{\mathrm{a}} \pm 0.09$ & $14.29^{b} \pm 5.67$ & ND & ND \\
\hline Solanum nigrum Linn & $0.82^{\mathrm{b}} \pm 0.08$ & $16.62^{\mathrm{b}} \pm 5.49$ & ND & ND \\
\hline Inga edulis Mart & ND & $11.45^{\mathrm{c}} \pm 6.34$ & ND & ND \\
\hline Hovenia dulcis Thunb & $0.56^{\mathrm{b}} \pm 0.21$ & $22.49^{\mathrm{a}} \pm 7.84$ & ND & ND \\
\hline \multicolumn{5}{|l|}{ Peel } \\
\hline Syzygium cumini Lam & $9.63^{\mathrm{a}} \pm 0.04$ & $18.32^{\mathrm{b}} \pm 7.98$ & ND & ND \\
\hline Solanum nigrum Linn & $0.53^{b} \pm 0.02$ & $57.38^{\mathrm{a}} \pm 12.46$ & ND & ND \\
\hline Inga edulis Mart & $\mathrm{NE}$ & $\mathrm{NE}$ & $\mathrm{NE}$ & $\mathrm{NE}$ \\
\hline Hovenia dulcis Thunb & $0.56^{\mathrm{b}} \pm 0.21$ & $22.49^{\mathrm{b}} \pm 7.84$ & ND & ND \\
\hline \multicolumn{5}{|l|}{ Seed } \\
\hline Syzygium cumini Lam & $57.10^{\mathrm{a}} \pm 5.67$ & $23.69^{\mathrm{b}} \pm 5.63$ & $4.81 \pm 0.57$ & $3.63 \pm 4.13$ \\
\hline Solanum nigrum Linn & $0.40^{\mathrm{c}} \pm 0.04$ & $21.87^{\mathrm{b}} \pm 6.92$ & ND & ND \\
\hline Inga edulis Mart & $0.81^{c} \pm 0.46$ & $12.24^{\mathrm{C}} \pm 4.13$ & ND & ND \\
\hline Hovenia dulcis Thunb & $34.61^{b} \pm 9.84$ & $28.77^{\mathrm{a}} \pm 5.25$ & ND & ND \\
\hline
\end{tabular}

Results expressed as mean \pm standard deviation of three replicates. Equivalent parts of the different fruits were compared. Means followed by different letters in the same column are significantly different by Tukey's test $(p<0.05)$. H. dulcis pulp and peel were evaluated together. ND $=$ not detected. NE $=$ not evaluated.

highest antioxidant capacity, probably due to having the highest TPC. Rufino et al. [9] evaluated the FRAP antioxidant capacity of methanolic extracts (methanol-water, $50: 50 \mathrm{v} / \mathrm{v}$ ) from the combined pulps and peels of S. cumini and found $35.5 \mu \mathrm{mol} \mathrm{Fe} e^{2+} / g$. This value was lower than that found in the current study, in pulp and peel of the same fruit (341.95 and $323.50 \mu \mathrm{mol} \mathrm{Fe}{ }^{2+} / \mathrm{g}$, respectively).

3.2. Identification of Phenolic Compounds by HPLC. The phenolic compounds responsible for the antioxidant capacity of the methanolic fruit extracts were gallic acid, kaempferol, epicatechin, and ellagic acid (with peak retention times of $3.6,5.4,14.7$, and $19.1 \mathrm{~min}$, respectively) (Table 3 ). The flavonoid, kaempferol, showed $\lambda_{\max }$ at $250 \mathrm{~nm}$ and epicatechin at $270 \mathrm{~nm}$. The gallic and ellagic acids also showed $\lambda_{\text {max }}$ at $270 \mathrm{~nm}$, characteristic of phenolic acids derived from hydroxybenzoic acid [25].

Gallic acid was the main contributor to the antioxidant capacity of S. cumini seeds $(57.10 \mathrm{mg} / 100 \mathrm{~g})$ and $H$. dulcis seeds $(34.61 \mathrm{mg} / 100 \mathrm{~g})$. S. cumini pulps presented $5.59 \mathrm{mg} / 100$ 
g of gallic acid, which was comparable to that found in walnut (3.39 mg/100 g) by Donno et al. [28]. As stated previously, phenolic compounds, such as gallic acid, exhibit potent antioxidant, antidiabetic, and antihyperlipidemic activities [29].

Although the $H$. dulcis pulp and peel showed the highest TPC content and the highest DPPH ${ }^{\circ}$ and FRAP antioxidant capacities, it did not have the highest content of gallic acid. This was probably due to the limited interaction between the extraction solvent and gallic acid due to the high reactivity of this phenolic compound with oxidative materials and macromolecules. These factors make the identification process complex [30].

Kaempferol ranged from $11.45 \mathrm{mg} / 100 \mathrm{~g}$ in $I$. edulis pulps to $57.38 \mathrm{mg} / 100 \mathrm{~g}$ in $S$. nigrum peels. Using HPLC-DAD/mass spectrometry, Donno et al. [5] found $0.55 \mathrm{mg} / 100 \mathrm{~g}$ of kaempferol in strawberries, being a value lower than that found in all parts of fruits in this study. Ellagic acid and epicatechin were only identified in S. cumini seeds (3.63 and $4.81 \mathrm{mg} / 100 \mathrm{~g}$, respectively). Epicatechin has been shown to exert several physiological effects, such as antioxidant activity and antitumor effects [31]. More recently, Rodríguez-Ramiro et al. [32] have shown that epicatechin was able to activate the detoxifying enzyme glutathione S-transferase pi 1 (GSTP1) related to the neutralization of reactive oxygen species and nitrogen species, in epithelial colon cells. Flavonols, like kaempferol and ellagic acid, possess health-promoting properties and may also contribute to the neutralization of free radicals and the maintenance of heart health $[28,33]$.

3.3. Fatty Acids (FAs). A total of eight FAs were detected in pulps, peels, and seeds of fruits (Table 4). S. nigrum peels presented $1212.20 \mathrm{mg} / 100 \mathrm{~g}$ in the sum of saturated fatty acid ( $\sum$ SFA), representing $87 \%$ of TL. Among the seeds, I. edulis presented the highest values of SFA, followed by $H$. dulcis ( $613.47 \mathrm{mg} / 100 \mathrm{~g}$ and $526.66 \mathrm{mg} / 100 \mathrm{~g}$, respectively), showing a significant difference between them.

S. nigrum seeds presented a value of $1895.10 \mathrm{mg} / 100 \mathrm{~g}$ in the sum of monounsaturated fatty acid ( $\sum$ MUFA), representing $62.45 \%$ of TL. The major MUFA found in these seeds was OA (18:1n-9), showing a value of $1891.36 \mathrm{mg} / 100 \mathrm{~g}$. This value of OA found was higher than those found by Santos et al. [13], in grape seed variety Isabel (1690.76 mg OA/100 g). The positive effect of dietary monounsaturated fats in preventing cancer has extensively been reported. In addition, the ingestion of this FA is associated with the improvement of the immune system due to its anti-inflammatory activity $[8,34]$.

$H$. dulcis seeds presented a value of $5921.07 \mathrm{mg} / 100 \mathrm{~g}$ in the sum of polyunsaturated fatty acid ( $\sum$ PUFA) $(78.32 \%$ TL). The main PUFA was LNA (18:3n-3), which was found at the highest concentration in $H$. dulcis seeds $(3985.95 \mathrm{mg} / 100 \mathrm{~g})$. These seeds contained $8.73 \%$ TL, with $53 \%$ represented by LNA. Various n-3 PUFAs have been reported to exert beneficial effects, such as cholesterol regulation, blood pressure reduction, and cardiovascular disease prevention [35, 36].

According to Simopoulos [37], the relationship between PUFA/SFA should be greater than 0.4 to be adequate to prevent heart disease. The ratio of $\sum$ SFA/ $\sum$ PUFA from all parts of the fruits has been higher than the recommended value, except in S. nigrum peels. This result was low because the peel of this fruit is rich in eicosanoic acid (20:0), presenting statistical difference among the other peels. This result also reflected the sum of saturated fatty acid ( $\sum$ SFA) of the $S$. nigrum peels $(1212.20 \mathrm{mg} / 100 \mathrm{~g})$, which was the largest among all the peels.

The high n-6 to n-3 ratio in the diets of Western countries which occurred after the introduction of modern agriculture and animal farming techniques has, at least partly, contributed to the rise in cardiovascular disease. Studies indicate that the human diet can decrease the chances of developing several diseases, so the nutrition societies recommend a healthy diet containing n- 6 to $n-3$ ratio of $5: 1[38,39]$. The $n-$ 6 to $n-3$ ratio of the fruits ranged within $2.38-51.01$ in pulps, $0.24-19.54$ in peels, and $0.06-78.30$ in seeds. All parts of the $H$. dulcis and the S. nigrum peels, S. cumini seeds, and I. edulis seeds presented an ideal ratio of n-6 to n-3.

3.4. Principal Component Analysis (PCA). PC1 (68.70\%) and PC2 $(21.73 \%)$ explained $90.43 \%$ of the total variance (Figure 1(a)). Loadings (variables)/score (samples) of antioxidant analyses of the fruits showed the formation of four groups (Figure 1(b)). One group consisted of DPPH ${ }^{\circ}$, FRAP, TPC, $\mathrm{TF}$, and sample 9, due to higher values in this sample, in all of these variables. In PC1, DPPH ${ }^{\circ}$, FRAP, TPC, and TF contributed positively to the separation of this group, whilst, in PC2, DPPH ${ }^{\circ}$, FRAP, and TPC contributed negatively and TF positively. Sample 2 was grouped with TA and also has highlighted the contents of this variable. Sample 3 showed high $\mathrm{DPPH}^{\bullet}$ and TPC values; for this reason, its position was closer to these variables and separated from the other samples. A fourth group was formed by the remaining samples, which showed lower values in all analyses.

PC1 and PC2 accounted for $93.80 \%$ of the total variance of the FA data (Figure 2(a)) and $66.21 \%$ (PC1) of this variance was attributed to the positive contribution of the sum of PUFAs, n-6 and n-3 (Figure 2(b)). Sample 10 showed the highest values for these variables, forming group 1. The PUFAs and n-3 loadings of this group contributed negatively and only n- 6 contributed positively to PC2, which accounted for $27.59 \%$ of the total variance. Sample 6 stood out in the MUFA values, contributing positively to PC2 and separating this group. The third group had the lowest values of the analyzed variables.

\section{Conclusion}

The bioactive compounds gallic acid and kaempferol were largely responsible for the antioxidant capacity of the parts of the fruits analyzed by HPLC, since the ellagic acid and the epicatechin were only found in S. cumini seeds. The parts of the fruits that stood out for their high TPC and TA contents showed a positive correlation between the contents of these compounds and the antioxidant capacity by the methods used. The PCA analysis showed that PC1 and PC2 explained $90.43 \%$ of the total variability of the antioxidant data. Most of the seeds studied showed omega-3, omega- 6 , and omega9 FAs, in significant concentrations, with two PCs explaining 


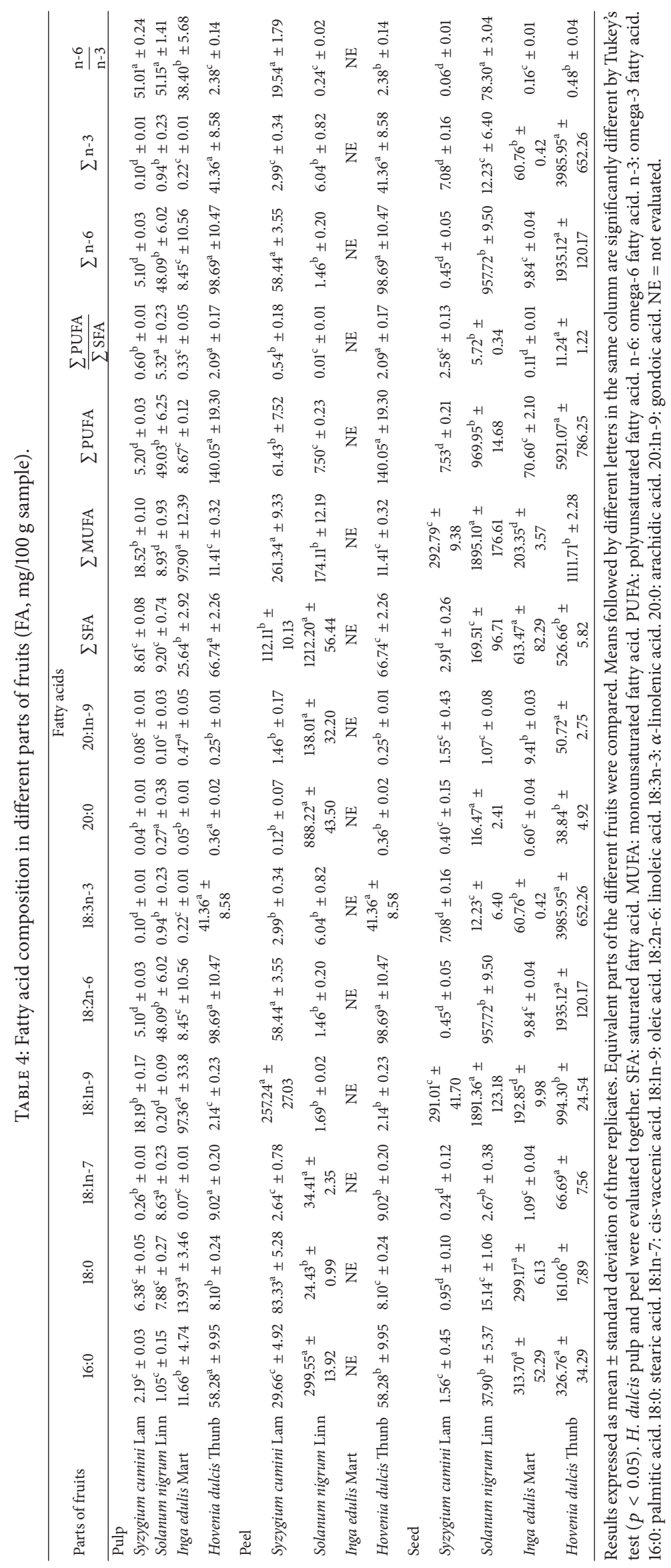




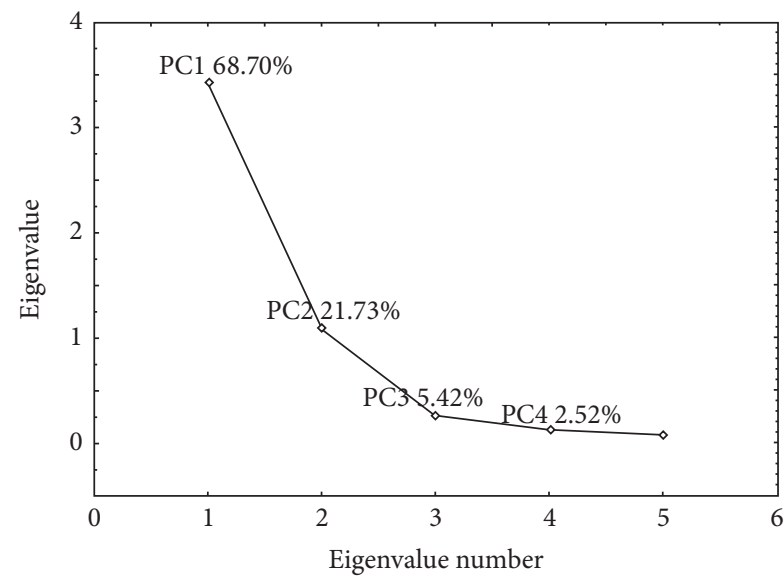

(a)

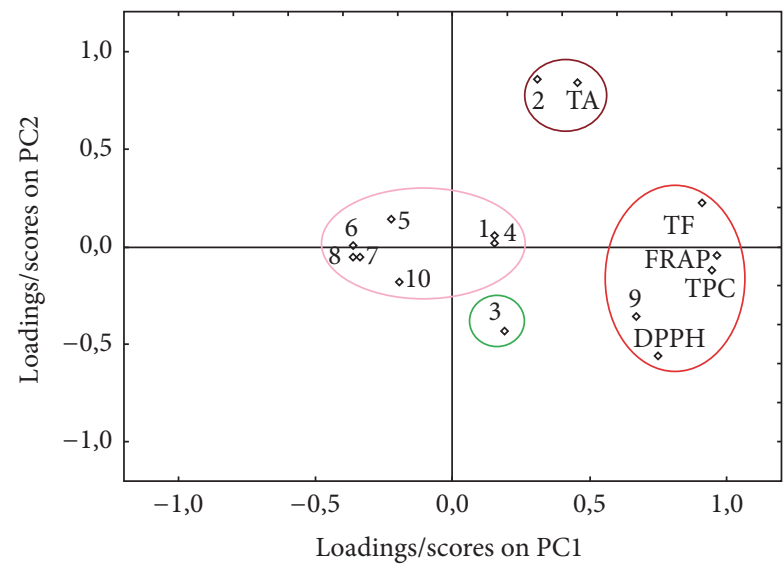

(b)

FIGURE 1: PC: principal component; (a) eigenvalue number; (b) loadings (variables)/scores (samples) biplot antioxidant analyses for the first and second PC of different parts of fruits: 1: S. cumini pulp; 2: S. cumini peel; 3: S. cumini seed; 4: S. nigrum pulp; 5: S. nigrum peel; 6: S. nigrum seed; 7: I. edulis pulp; 8: I. edulis seed; 9: H. dulcis pulp and peel; 10: H. dulcis seed.

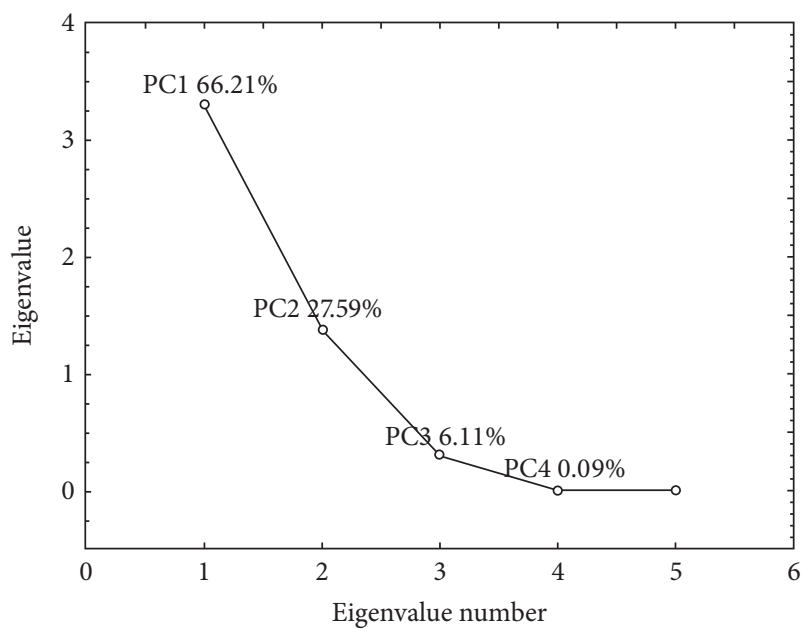

(a)

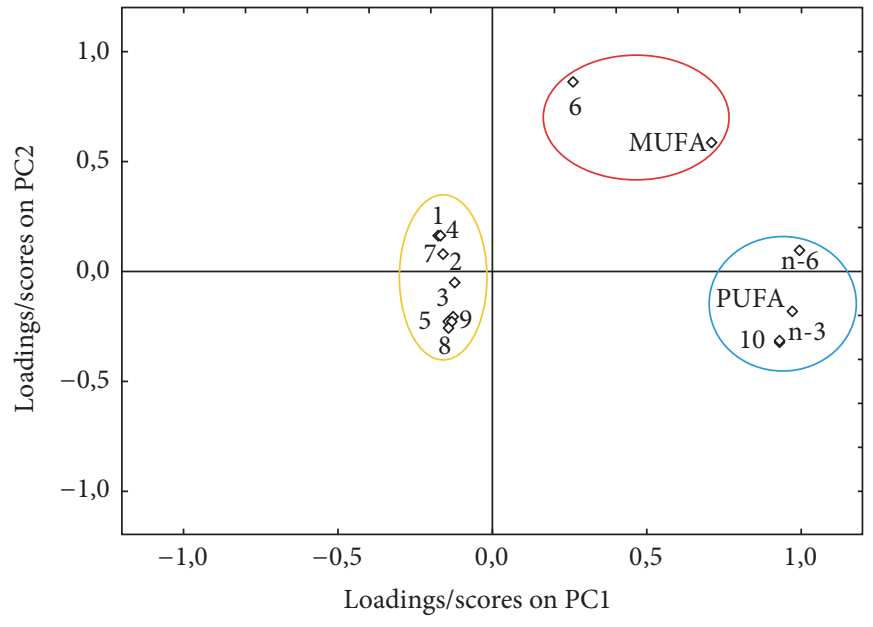

(b)

FiguRe 2: PC: principal component; (a) eigenvalue number; (b) loadings (variables)/scores (samples) biplot of fatty acids for the first and second PC of different parts of fruits: 1: S. cumini pulp; 2: S. cumini peel; 3: S. cumini seed; 4: S. nigrum pulp; 5: S. nigrum peel; 6: S. nigrum seed; 7: I. edulis pulp; 8: I. edulis seed; 9: H. dulcis pulp and peel; 10: H. dulcis seed.

93.80\% of the contribution of these FA contents and the sum of the MUFAs and PUFAs to these data.

\section{Conflicts of Interest}

The authors declare that there are no conflicts of interest regarding the publication of this paper.

\section{Acknowledgments}

The authors would like to thank the Coordenação de Aperfeiçoamento de Pessoal de Nível Superior (CAPES) and the Conselho Nacional de Desenvolvimento Científico e Tecnológico $(\mathrm{CNPq})$ for their financial support and fellowships.

\section{References}

[1] B. Halliwell, "Free radicals and antioxidants: updating a personal view," Nutrition Reviews, vol. 70, no. 5, pp. 257-265, 2012.

[2] R. L. Prior, "Oxygen radical absorbance capacity (ORAC): new horizons in relating dietary antioxidants/bioactives and health benefits," Journal of Functional Foods, vol. 18, pp. 797-810, 2015.

[3] T. M. Rababah, N. S. Hettiarachy, and R. Horax, "Total phenolics and antioxidant activities of fenugreek, green tea, black tea, grape seed, ginger, rosemary, gotu kola, and ginkgo extracts, vitamin E, and butylhydroquinone," Journal of Agricultural and Food Chemistry, vol. 52, no. 16, pp. 5183-5186, 2004.

[4] M. E. Schreckinger, J. Lotton, M. A. Lila, and E. G. De Mejia, "Berries from South America: a comprehensive review on chemistry, health potential, and commercialization," Journal of Medicinal Food, vol. 13, no. 2, pp. 233-246, 2010. 
[5] D. Donno, M. Cananna, G. L. Beccaro, M. G. Mellano, D. T. Marioni, and A. K. G. Bounous, "Currants and strawberries as bioactive compound sources: determination of antioxidant profiles with HPLC-DAD/MS system," Journal of Applied Botany and Food Quality, vol. 86, pp. 1-10, 2013.

[6] A. C. Aguiar, S. M. Cottica, M. Boroski et al., "Quantification of essential fatty acids in the heads of nile tilapia (Oreochromis niloticus) fed with linseed oil," Journal of the Brazilian Chemical Society, vol. 22, no. 4, pp. 643-647, 2011.

[7] I. Gülçin, "Antioxidant activity of food constituents: an overview," Archives of Toxicology, vol. 86, no. 3, pp. 345-391, 2012.

[8] S. Bilal, A. L. Khan, M. Waqas et al., "Biochemical constituents and in vitro antioxidant and anticholinesterase potential of seeds from Native Korean Persimmon Genotypes," Molecules, vol. 21, no. 7, article 893, 2016.

[9] M. D. S. M. Rufino, R. E. Alves, E. S. de Brito, J. Pérez-Jiménez, F. Saura-Calixto, and J. Mancini-Filho, "Bioactive compounds and antioxidant capacities of 18 non-traditional tropical fruits from Brazil," Food Chemistry, vol. 121, no. 4, pp. 996-1002, 2010.

[10] M. M. Root, M. C. Mcginn, D. C. Nieman et al., "Combined fruit and vegetable intake is correlated with improved inflammatory and oxidant status from a cross-sectional study in a community setting," Nutrients, vol. 4, no. 1, pp. 29-41, 2012.

[11] J. Pérez-Jiménez, S. Arranz, M. Tabernero et al., "Updated methodology to determine antioxidant capacity in plant foods, oils and beverages: extraction, measurement and expression of results," Food Research International, vol. 41, no. 3, pp. 274-285, 2008.

[12] R. Apak, M. Özyürek, K. Güçlü, and E. Çapanoğlu, “Antioxidant activity/capacity measurement.1. Classification, physicochemical principles, mechanisms, and electron transfer (ET)-based assays," Journal of AOAC International, vol. 64, pp. 997-1027, 2016.

[13] L. P. Santos, D. R. Morais, N. E. Souza, S. M. Cottica, M. Boroski, and J. V. Visentainer, "Phenolic compounds and fatty acids in different parts of Vitis labrusca and V. vinifera grapes," Food Research International, vol. 44, no. 5, pp. 1414-1418, 2011.

[14] W. Brand-Williams, M. E. Cuvelier, and C. Berset, "Use of a free radical method to evaluate antioxidant activity," LWT-Food Science and Technology, vol. 28, no. 1, pp. 25-30, 1995.

[15] I. F. F. Benzie and J. J. Strain, "The ferric reducing ability of plasma (FRAP) as a measure of 'antioxidant power': the FRAP assay," Analytical Biochemistry, vol. 239, no. 1, pp. 70-76, 1996.

[16] F. Shahidi and M. Naczk, Food Phenolics: Sources, Chemistry, Effects and Applications, Technomic Publishing Company, Lancaster, UK, 1995.

[17] R. G. Woisky and A. Salatino, "Analysis of propolis: Some parameters and procedures for chemical quality control," Journal of Apicultural Research, vol. 37, no. 2, pp. 99-105, 1998.

[18] D. H. Lees and F. J. Francis, "Standardization of pigment analyses in cranberries," HortScience, vol. 7, pp. 83-84, 1972.

[19] E. G. Bligh and W. J. Dyer, "A rapid method of total lipid extraction and purification," Canadian Journal of Physiology and Pharmacology, vol. 37, no. 8, pp. 911-917, 1959.

[20] L. Hartman and R. C. A. Lago, "Rapid preparation of fatty acid methyl esters from lipids," Laboratory Practice, vol. 22, no. 7, pp. 475-476, 1973.

[21] J. D. Joseph and R. G. Ackman, "Capillary column gas chromatography method for analysis of encapsulated fish oil and fish oil ethyl esters: collaborative study," Journal of AOAC International, vol. 75, pp. 488-506, 1992.
[22] J. V. Visentainer, "Aspectos analíticos da resposta do detector de ionização em chama para ésteres de ácidos graxos em biodiesel e alimentos," Química Nova, vol. 35, no. 2, pp. 274-279, 2012.

[23] F. Fratianni, M. Tucci, M. D. Palma, R. Pepe, and F. Nazzaro, "Polyphenolic composition in different parts of some cultivars of globe artichoke (Cynara cardunculus L. var. scolymus (L.) Fiori)," Food Chemistry, vol. 104, no. 3, pp. 1282-1286, 2007.

[24] A. C. Volp, I. R. T. Renhe, K. B. Barra, and P. C. Stringueta, "Flavonóides antocianinas: características e propriedades na nutrição e saúde," Revista brasileira de nutrição clínica, vol. 23, pp. 141-149, 2008.

[25] A. F. Faria, M. C. Marques, and A. Z. Mercadante, "Identification of bioactive compounds from jambolão (Syzygium cumini) and antioxidant capacity evaluation in different $\mathrm{pH}$ conditions," Food Chemistry, vol. 126, no. 4, pp. 1571-1578, 2011.

[26] P. S. Benherlal and C. Arumughan, "Chemical composition and in vitro antioxidant studies on Syzygium cumini fruit," Journal of the Science of Food and Agriculture, vol. 87, no. 14, pp. 25602569, 2007.

[27] C. Vasco, J. Ruales, and A. Kamal-Eldin, "Total phenolic compounds and antioxidant capacities of major fruits from Ecuador," Food Chemistry, vol. 111, no. 4, pp. 816-823, 2008.

[28] D. Donno, R. Boggia, P. Zunin et al., "Phytochemical fingerprint and chemometrics for natural food preparation pattern recognition: an innovative technique in food supplement quality control," Journal of Food Science and Technology, vol. 53, no. 2, pp. 1071-1083, 2016.

[29] T. Suzuki, S. Someya, F. Hu, and M. Tanokura, "Comparative study of catechin compositions in five Japanese persimmons (Diospyros kaki)," Food Chemistry, vol. 93, no. 1, pp. 149-152, 2005.

[30] J. M. Monteiro, U. P. De Albuquerque, E. L. De Araújo, and E. L. C. De Amorim, "Taninos: uma abordagem da química à ecologia," Química Nova, vol. 28, no. 5, pp. 892-896, 2005.

[31] N. J. Kang, K. W. Lee, D. E. Lee et al., "Cocoa procyanidins suppress transformation by inhibiting mitogen-activated protein kinase kinase," Journal of Biological Chemistry, vol. 283, no. 30, pp. 20664-20673, 2008.

[32] I. Rodríguez-Ramiro, S. Ramos, L. Bravo, L. Goya, and M. Á. Martín, "Procyanidin B2 induces Nrf2 translocation and glutathione S-transferase P1 expression via ERKs and p38-MAPK pathways and protect human colonic cells against oxidative stress," European Journal of Nutrition, vol. 51, no. 7, pp. 881-892, 2012.

[33] H. Wang, F. Feng, B.-Y. Zhuang, and Y. Sun, "Evaluation of hepatoprotective effect of Zhi-Zi-Da-Huang decoction and its two fractions against acute alcohol-induced liver injury in rats," Journal of Ethnopharmacology, vol. 126, no. 2, pp. 273-279, 2009.

[34] C. Romero, M. V. Ruiz-Méndez, and M. Brenes, "Bioactive compounds in virgin olive oil of the pdo montoro-adamuz," JAOCS, Journal of the American Oil Chemists' Society, pp. 665672, 2016.

[35] D. Kromhout, S. Yasuda, J. M. Geleijnse, and H. Shimokawa, "Fish oil and omega-3 fatty acids in cardiovascular disease: do they really work?” European Heart Journal, vol. 33, no. 4, pp. 436-443, 2012.

[36] C. Moreno, A. Macías, A. Prieto, A. de la Cruz, T. González, and C. Valenzuela, "Effects of n-3 polyunsaturated fatty acids on cardiac ion channels," Frontiers in Physiology, vol. 3, article $245,2012$. 
[37] A. P. Simopoulos, "Omega-3 fatty acids in inflammation and autoimmune diseases," Journal of the American College of Nutrition, vol. 21, no. 6, pp. 495-505, 2002.

[38] R. De Caterina, R. Madonna, R. Zucchi, and M. T. La Rovere, "Antiarrhythmic effects of omega-3 fatty acids: from epidemiology to bedside," American Heart Journal, vol. 146, no. 3, pp. 420-430, 2003.

[39] DACH, Referenzwerte Für Die Nährstoffzufuhr, Umschau/Braus $\mathrm{GmbH}$, Frankfurt, Germany, 1st edition, 2002. 

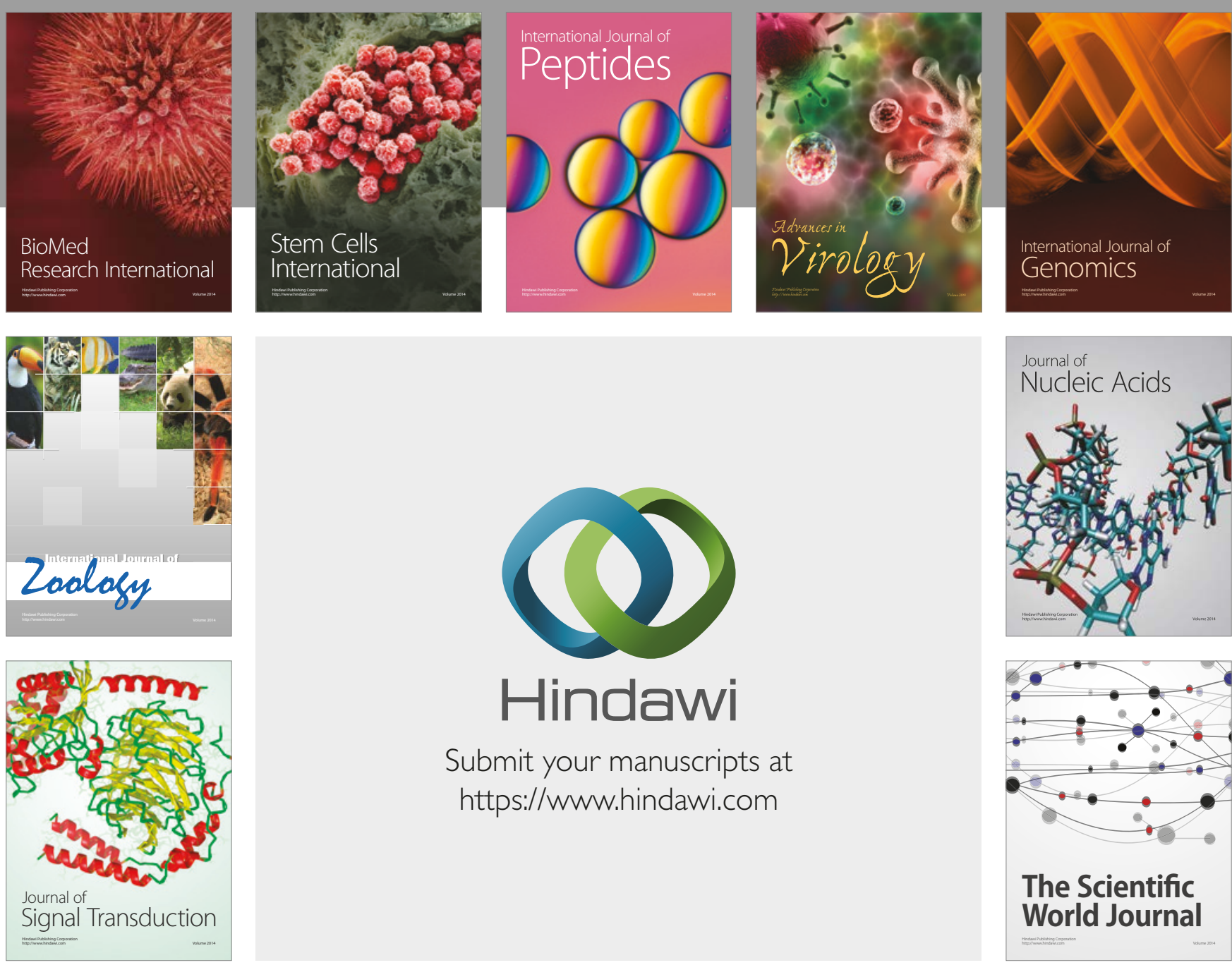

Submit your manuscripts at

https://www.hindawi.com
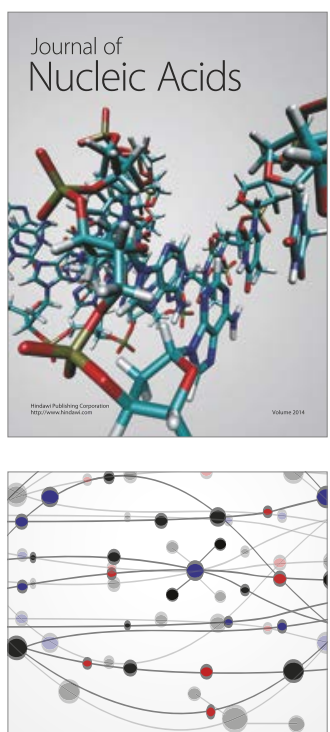

The Scientific World Journal

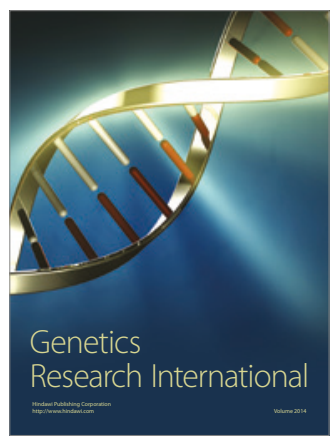

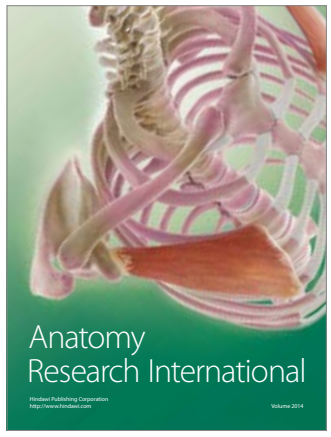

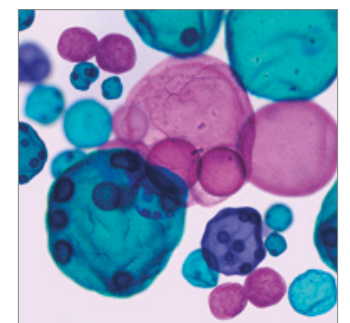

International Journal of Microbiology
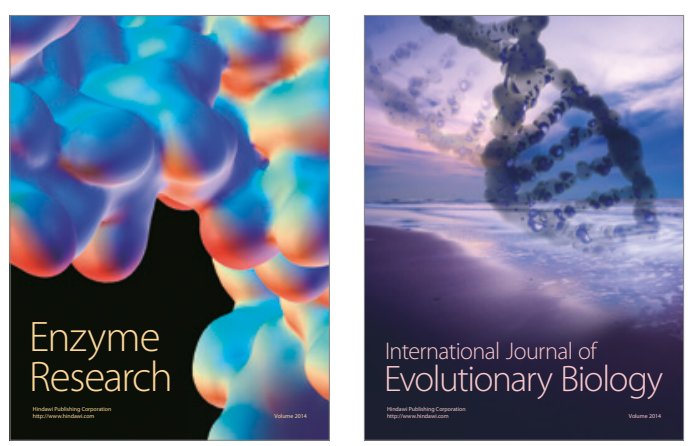
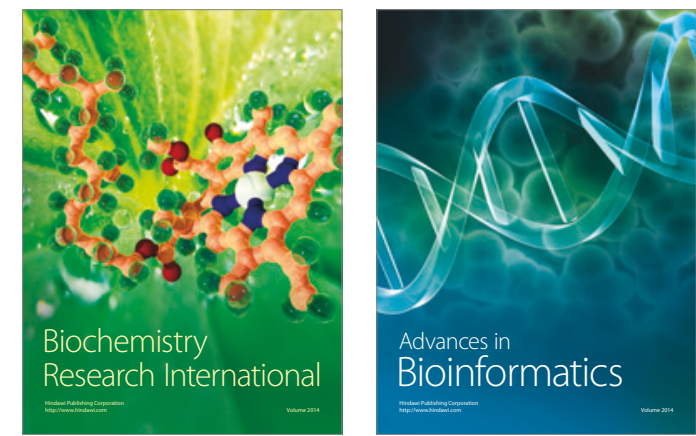

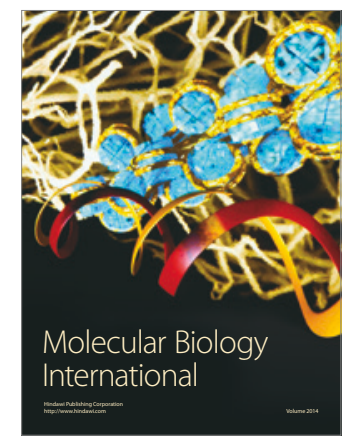

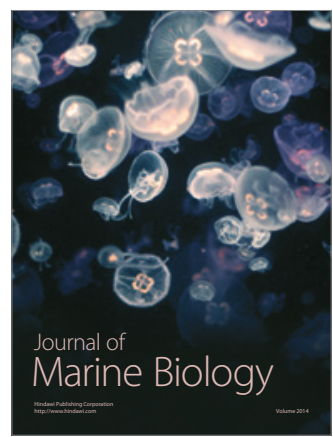

